\title{
Caddo Ceramics from 41CV41A at Fort Hood, Coryell County, Texas
}

Timothy K. Perttula

Heritage Research Center, Stephen F. Austin State University

Follow this and additional works at: https://scholarworks.sfasu.edu/ita

Part of the American Material Culture Commons, Archaeological Anthropology Commons, Environmental Studies Commons, Other American Studies Commons, Other Arts and Humanities Commons, Other History of Art, Architecture, and Archaeology Commons, and the United States History Commons

Tell us how this article helped you.

This Article is brought to you for free and open access by the Center for Regional Heritage Research at SFA ScholarWorks. It has been accepted for inclusion in Index of Texas Archaeology: Open Access Gray Literature from the Lone Star State by an authorized editor of SFA ScholarWorks. For more information, please contact cdsscholarworks@sfasu.edu. 


\section{Caddo Ceramics from 41CV41A at Fort Hood, Coryell County, Texas}

Creative Commons License

(c) (i) (8)

This work is licensed under a Creative Commons Attribution-NonCommercial 4.0 International License 


\title{
CADDO CERAMICS FROM 41CV41A AT FORT HOOD, CORYELL COUNTY, TEXAS
}

\author{
Timothy $K$. Perttula \\ INTRODUCTION
}

Prehistoric Caddo ceramics made in Northeast Texas after ca. A.D. 900 were widely traded in Texas, and other parts of the Caddoan area, being found in some quantity on North central, East central, central, and inland Southeast Texas archeological sites (Story 1990:247; Perttula et al. 1995). They were also traded with prehistoric peoples in the Midwest, the southeastern U.S., and the southem Plains. However, the ceramic evidence for prehistoric Caddoan trade and exchange with other Native Americans has not been systematically compiled and studied for the prehistoric and historic periods. Consequently, it is impossible to confidently discuss the scope, timing, or direction of trade/exchange between Caddoan groups and surrounding non-Caddoan communities, or explore changes in the nature of social and economic relationships between particular Caddo groups and with other prehistoric peoples.

Over the last several years, I have been attempting to systematically document archeological information on the distribution and character of Caddoan ceramic sherds and vessels both within and outside what is considered the southern Caddoan archeological area (see Perttula 1998a, 1999a; Perttula et al. 1995, 1996). This documentation effort has included instrumental neutron activation analysis by the Missouri University Research Reactor, petrographic analyses, and studies of ceramic styles and pastes. Here, I discuss Caddo ceramics from 41CV41A that were recently recovered in archeological investigations by Prewitt and Associates, Inc. at Fort Hood in Central Texas.

\section{Description of the Caddo Ceramics from $41 \mathrm{CV} 41 \mathrm{~A}$}

The seven Caddo ceramic sherds from 41CV41A are from the same vessel, an engraved bottle of Late Caddoan design, and the sherds are from the vessel body. The sherds are from Feature 2 in TU 2, with six (two are conjoinable) found between 10-20 cm below surface (bs), and the seventh found between $20-30 \mathrm{~cm}$ bs.

The bottle is well-made by coiling, and it has been fired in a reducing environment, as its core is black. The exterior is also black in color, and it has been polished; the interior of the vessel is gray and unsmoothed, with the exception of a few wipe marks on several of the sherds. The vessel body walls range from 5.6-6.8 $\mathrm{mm}$ in thickness, and the clay paste is sandy, with small amounts of grog and hematite added to the paste as temper.

The bottle sherds appear to be from a Taylor Engraved vessel (see Suhm and Jelks 1962:Plate 76M, a vessel from the Taylor site [41HS3] in Harrison County, Texas). One larger sherd from $10-20 \mathrm{~cm}$ bs has three closely-spaced engraved lines that may be from a series of concentric circles centered on the vessel body, with an intersecting engraved line with two small excised triangles pendant from the line (Figure 1f). Along the outermost concentric engraved line is a scroll that has been well-defined by closely spaced crosshatched engraved lines. Four other sherds from $10-20 \mathrm{~cm}$ bs have portions of the crosshatched engraved scroll (Figure 1b-e). The one sherd from $20-30 \mathrm{~cm}$ bs has a portion of the cross-hatched engraved scroll and a curvilinear engraved line parallel to it with two excised triangles pendant from the line (Figure la). 

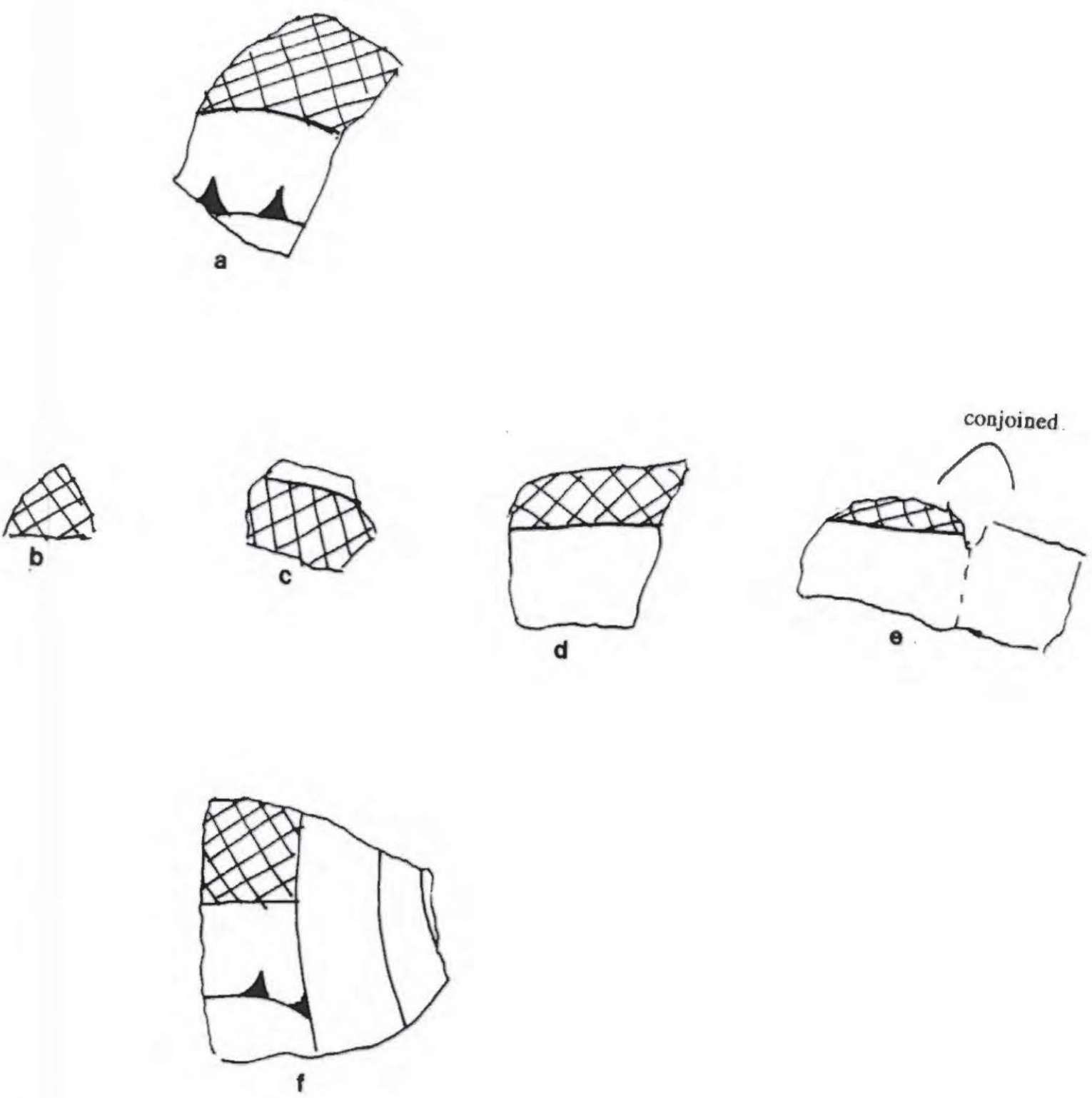

Figure 1. Caddo ceramics from 41CV41A: a, TU 2, Feature 2, 20-30 cm; b-f, TU 2, Feature 2, $10-20 \mathrm{~cm}$ bs. 
Taylor Engraved is commonly found in Titus phase contexts in the Big Cypress Creek basin in Northeast Texas. The Titus phase dates from ca. A.D. 1430-1680 (Perttula 1998b). In the Titus phase, Taylor Engraved vessels are recovered principally from mortuary features that date to the latter part of the 16th and much of the 17th century (Perttula 1992:248-249 and Table A-1).

The manufacturing locales for Taylor Engraved have not yet been determined by either neutron activation analyses or petrographic studies. However, Cogswell et al. (1999) have defined four distinct chemical compositional groups--Red River, Titus, Rusk, and Hurricane-1--in Middle to Late Caddoan ceramic assemblages from Northeast Texas, and the sample of $170+$ sherds subjected to neutron activation analysis to date should be sufficiently robust to be able to determine the likely compositional origin of the Taylor Engraved bottle sherds from 4ICV41A.

There is also a petrographic database of more than 250 Caddoan sherds from Northeast Texas (Perttula 1999b:Table 9-13). A summary examination of compositional differences in non-plastics, matrix, pore space, temper, and detrital grains of quartz, feldspar, and hematite in these petrographic thin-sections (Perttula 1999b:Table 9-14) have identified distinct inter and intra-regional and stream basin differences based primarily on east-west or upper basin-lower basin trends in the depletion of minerals and rare earths from west to east and the use of clay sources with immature or mature sands or sandstone. Thin section point counts of the paste composition of the Taylor Engraved sherds from 4ICV41A should be obtained to help establish the river/creek basin source of the clays used to manufacture this trade vessel.

\section{Possible Ceramic Pipe Sherd from 41CV41A}

In addition to the Caddo ceramics found in Feature 2 at 41 CV41A, there is a small and poorly fired sherd from what appears to be the rim to a vasiform-shaped Toyah phase smoking pipe (see Ricklis 1994:Figure 143). The sherd has been incompletely oxidized during firing, and the exterior surface is pocked and rough, while the interior has been poorly smoothed. The surface color is light gray to buff. The possible pipe sherd is only $2.8 \mathrm{~mm}$ in thickness.

\section{ACKNOWLEDGMENTS}

I would like to thank Doug Boyd of Prewitt and Associates, Inc. for the opportunity to examine the Caddo ceramics from 4ICV41A, and for taking such an active role in launching the petrographic and neutron activation analyses of other Caddo sherds from sites in Central Texas.

\section{REFERENCES CITED}

Cogswell, J. W., H. Neff, and M. D. Glascock

1999 Chemical Variation in Northeastern Texas Ceramics. In The Archeology of the Roitsch Site (4IRR 16), an Early to Historic Caddo Period Village on the Red River in Northeast Texas, edited by T. K. Perttula. MS in preparation. Red River Field School, Technical Report, Volume I. Texas Historical Commission, Austin.

Perttula, T. K.

1992 "The Caddo Nation": Archaeological \& Ethnohistoric Perspectives. University of Texas Press, Austin. 
1998a Decorated Caddoan Ceramics from Two Sites on the Elm Fork of the Trinity River, Dallas County, Texas. Journal of Northeast Texas Archaeology 11:49-54.

1998b Late Caddoan Societies in the Northeast Texas Pineywoods. In The Native History of the Caddo:Their Place in Southeastern Archeology and Ethnohistory, edited by T. K. Perttula and J. E. Bruseth, pp. 69-90. Studies in Archeology 30. Texas Archeological Research Laboratory, The University of Texas at Austin.

1999a Ceramic Evidence for Prehistoric Caddoan Trade and Exchange. Mini-NSF Grant Proposal on file, Missouri University Research Reactor, Columbia.

1999b (Editor) The Hurricane Hill Site (41HP106): The Archaeology of a Late Archaic/Early Ceramic and Early-Middle Caddoan Settlement in Northeast Texas. 2 Vols. Special Publication No. 4. Friends of Northeast Texas Archaeology, Pittsburg and Austin.

Perttula, T. K., E. R. Martin, and B. Nelson

1996 Caddo Ceramics on the Red River in North Central Texas. Journal of Northeast Texas Archaeology 8:51-57.

Perttula, T. K., M. R. Miller, R. A. Ricklis, D. J. Prikryl, and C. Lintz

1995 Prehistoric and Historic Aboriginal Ceramics in Texas. Bulletin of the Texas Archeological Society 66:175-235.

Ricklis, R. A.

1994 Toyah Components: Evidence for Occupation in the Project Area During the Latter Part of the Late Prehistoric Period. In Archaic and Late Prehistoric Human Ecology in the Middle Onion Creek Valley, Hays County, Texas, by R. A. Ricklis and M. B. Collins, pp. 207-316. Studies in Archeology 19. Texas Archeological Research Laboratory, The University of Texas at Austin.

Story, D. A.

1990 Cultural History of the Native Americans. In The Archeology and Bioarcheology of the Gulf Coastal Plain, by D. A. Story, J. A. Guy, B. A. Burnett, M. D. Freeman, J. C. Rose, D. G. Steele, B. W. Olive, and K. J. Reinhard, pp. 163-366. Research Series No. 38. Arkansas Archeological Survey, Fayetteville.

Suhm, D. A. and E. B. Jelks

1962 Handbook of Texas Archeology: Type Descriptions. Texas Archeological Society, Special Publication No. 1, and Texas Memorial Museum, Bulletin No. 4, Austin. 